\title{
Screening of fungi from the genus Penicillium for production of $\beta$ - fructofuranosidase and enzymatic synthesis of fructooligosaccharides
}

\author{
A.K.C. Nascimento ${ }^{a}$, C. Nobre ${ }^{b}$, M.T.H. Cavalcanti ${ }^{a}, *$, J.A. Teixeira ${ }^{b}$, A.L.F. Porto ${ }^{a}$ \\ a Department of Morphology and Animal Physiology, Federal Rural University of Pernambuco-UFRPE, Av. Dom Manoel de Medeiros, s/n, 52171-900 Recife, \\ PE, Brazil \\ ${ }^{\mathrm{b}}$ Centre of Biological Engineering, University of Minho, Campus de Gualtar, 4710-057 Braga, Portugal
}

\section{A R T I C L E I N F O}

\section{Article history:}

Received 3 May 2016

Received in revised form 3 September 2016

Accepted 5 September 2016

Available online 6 September 2016

\section{Keywords:}

Penicillium citreonigrum

$\beta$-Fructofuranosidase

Fructooligosaccharides

\begin{abstract}
A B S T R A C T
Eight new isolated fungi of the genus Penicillium were evaluated for $\beta$-fructofuranosidase (FFase) production. From these, Penicillium citreonigrum was selected for FFase and fructooligosaccharides (FOS) production. The influence of temperature, yeast extract concentration, $\mathrm{pH}$ and fermentation time on the FFase activity when using the whole microorganism was evaluated by $2^{4}$ and $2^{3}$ designs. The $\mathrm{pH}$ was set at 6.5 and no yeast extract was used in the optimization experiments since both shown low significant effects on FFase activity. After optimization, temperature and fermentation time, were set to $25.5^{\circ} \mathrm{C}$ and $67.8 \mathrm{~h}$. Under these conditions, the model predicted a FFase production of $301.84 \mathrm{U} / \mathrm{mL}$. The scaled-up process in a $2 \mathrm{~L}$ bioreactor enhanced the enzyme productivity up to 1.5 times $(6.11 \mathrm{U} / \mathrm{mL} \mathrm{h})$. A concentration of $58.7 \mathrm{~g} / \mathrm{L}$ of FOS was obtained, where kestose was the main product. Assays performed for enzyme characterization showed that $50^{\circ} \mathrm{C}$ and a pH 5.0 are the optimal conditions for FFase activity. FFase showed to be stable at temperatures between 25 and $30^{\circ} \mathrm{C}$ and $\mathrm{pH} 4.0-10.0$ and its activity increased in the presence of ions, especially $\mathrm{Cu}^{4+}$. Results obtained in this primary report are a clear indication on the interest of using $P$. citreonigrum as a source of FFase for further FOS production.
\end{abstract}

(c) 2016 Elsevier B.V. All rights reserved.

\section{Introdution}

Enzymes named $\beta$-fructofuranosidases (FFase) are located in the GH32 family of the glycosil hydrolases and grouped in different isoforms according to their $\mathrm{pH}$ of action as acid, alkaline and neutral enzymes [1]. At high sucrose concentration, some FFase are able to catalyze transfructosylation reactions synthesizing fructooligosaccharides (FOS) [2]. Most of these enzymes have been found in fungi such as Aureobasidium spp., Aspergillus spp. and Penicillium spp. $[3,4]$.

FOS are carbohydrates naturally found in small quantities in several plants, though their concentrations are generally too small for produce a significant beneficial effect in humans. For large scale production, enzymes derived from microorganisms such as $\beta$ fructofuranosidases (FFase) (EC 3.2.1.26) and fructosyltransferases (FTase) (EC 2.4.1.9) are used [5,6].

Structurally, FOS are non-conventional sugars, namely, kestose $\left(\mathrm{GF}_{2}\right)$, nystose $\left(\mathrm{GF}_{3}\right)$ and fructofuranosylnystose $\left(\mathrm{GF}_{4}\right)$, composed by $\beta(2 \rightarrow 1)$-linked fructose $(F)$ units attached to a terminal glu-

\footnotetext{
* Corresponding author.

E-mail address: mtcvsoares@yahoo.com.br (M.T.H. Cavalcanti).
}

cose ( $\mathrm{G})$ moiety by a $\alpha(2 \rightarrow 1)$ linkage [7]. These oligosaccharides are important prebiotics since their daily intake is related with many health benefits such as: reducing the incidence of intestinal infections, protection against colon cancer, improving mineral absorption, decreasing total cholesterol and lipid blood serum, and an overall improvement of human health $[8,9]$.

For this reason, a rapid market growth on FOS has emerged in the recent years, all over the world. The current largest world market for prebiotic food is the Europe. Asia-Pacific is forecast to emerge as the fastest growing market with a compound annual growth rate (CAGR) of $14 \%$ over the analysis period. According to Global Industry Analysts (GIA) report, the global market for prebiotics is projected to surpass $\$ 5.9$ billion by 2020 , driven by expanding applications beyond the food industry and into the animal feed sector [10].

To meet market needs, it is essential keep searching for new microbial strains with potential for FFase production and enzymatic synthesis of FOS. However, the cost of enzyme production and purification is one of the main factors limiting their industrial application. This cost can be reduced by optimizing the fermentation strategies, operational conditions and culture medium composition using statistical tools such as response surface methodology (RSM) to increase enzyme activity. 
The RSM is a powerful technique for testing multiple process variables because fewer experimental trials are needed. Conventional method of optimization involves varying one parameter at a time and keeping others constant. This method is extremely time consuming and often does not bring about the effect of interaction of various parameters [11]. The single dimensional search is laborious and less capable of reaching true optimum due to interactions among variables [12].

Therefore, the aim of this work was the screen and identification of new isolated strains of Penicillium fungi with potential for FFase enzyme production. Experimental conditions for FFase production and FOS synthesis were optimized for the strain selected, in shaken flask and bioreactor, using successive experimental designs. The isolated FFase was also characterized regarding its optimal $\mathrm{pH}$, temperature, stability and effect of ions in its enzymatic activity.

\section{Experimental}

\subsection{Chemicals}

FOS standards (1-kestose, 1-nystose, and 1- $\beta$ fructofuranosylnystose) were purchased in Wako Pure Chemical Industries, Ltd. (Japan Company). Sugars sucrose and fructose were obtained from Merck (USA) and glucose from VWR (Belgium). A glucose-oxidase-peroxidase enzymatic kit was obtained from Labtest (Brazil). Other reagents were purchased from Sigma Chemical (St. Louis, MO, USA), Merck (Darmstadt,Germany), Oxoid (England) or Himedia (India).

\subsection{Microorganisms and culture conditions}

Eight strains belonging to the Penicillium genus were investigated for FFase production. The fungi were obtained from Micoteca of the Federal University of Pernambuco (URM - UFPE). The strains tested, $P$. aurantiogriseum (URM 5139), P. citrinum (URM 2725), $P$. commune (URM 4939), P. aurantiogriseum (URM 5126), P. implicatum (URM 5426), P. citreonigrum (URM 4459), P. glabrum (URM 4757), P. islandicum (URM 5073), were grown and maintained on Czapek Dox Agar medium at $4{ }^{\circ} \mathrm{C}$. A concentrated spore solution wasobtained from a 7 days growing in a Czapek Dox agar medium at $30^{\circ} \mathrm{C}$. Spores were scraped from the plates with a sterile solution of Tween 80 at $0.1 \%(\mathrm{w} / \mathrm{v})$. The number of spores in the concentrated solution was determined by counting in a microscope, using an improved Neubauer chamber. The suspension was finally diluted to a concentration of $10^{4}$ spores $/ \mathrm{mL}$.

\subsection{Screening of fungi for FFase production}

A $35 \mu \mathrm{L}$ volume of a spore suspension $\left(10^{4}\right.$ spores $\left./ \mathrm{mL}\right)$ was transferred to a $250 \mathrm{~mL}$ shaken flask containing $100 \mathrm{~mL}$ of fermentation medium with the following composition $(\% \mathrm{w} / \mathrm{v})$ : sucrose, 20.0; yeast extract, 2.75; $\mathrm{NaNO}_{3}, 0.2 ; \mathrm{MgSO}_{4} \cdot 7 \mathrm{H}_{2} \mathrm{O}, 0.05 ; \mathrm{K}_{2} \mathrm{HPO}_{4}$, 0.5 ; and $\mathrm{KCl}, 0.05$ [13]. The culture medium was previously autoclaved at $121^{\circ} \mathrm{C}$ for $15 \mathrm{~min}$ and the $\mathrm{pH}$ was adjusted to 5.50 before inoculation. Fermentations were carried out at $30^{\circ} \mathrm{C}$ under an agitation of $150 \mathrm{rpm}$. Samples were harvested at 0,12,16, 20, 24 and $36 \mathrm{~h}$ of fermentation. At the end of fermentation, cultures were firstly vacuum filtered with a Whatman paper number 1 , for cell pellets removal. The filtrated solution obtained was used for extracellular FFase activity determination and FOS quantification after re-filtration through a $0.2-\mu \mathrm{m}$ cut-off filter.

\subsection{Determination of FFase transfructosylation activity}

The FFase transfructosylation activity was determined according to the method described by Ganaie et al. [14], using sucrose as substrate, at a concentration of $60 \%(\mathrm{w} / \mathrm{v})$, in citrate buffer, at $\mathrm{pH}$ 6.0. The absorbance of glucose released was read at $505 \mathrm{~nm}$ on Synergy ${ }^{\mathrm{TM}}$ HT Multi-Mode Microplate Reader (BioTek, USA) using an enzymatic glucose determination kit. The units of FFase activity were defined as the amount of enzyme required to release $1 \mu \mathrm{mol}$ of glucose per minute.

\subsection{Sugar analysis}

FOS (1-kestose, 1-nystose, and 1- $\beta$-fructofuranosylnystose), fructose, glucose and sucrose were analyzed using highperformance liquid chromatography (HPLC) using a LC-10 A equipment (Jasco, Japan) equipped with a Prevail Carbohydrate ES column $(5 \mu \mathrm{m}, 250 \times 4.6 \mathrm{~mm}$, Alltech). Sugars were detected with an evaporative light scattering detector, Sedex 85 (Sedere). A mixture of acetonitrile and water containing $0.04 \%$ ammonium hydroxide $(70: 30 \mathrm{v} / \mathrm{v})$ was used as mobile phase, at a flow rate of $1.0 \mathrm{~mL} / \mathrm{min}$ and $25^{\circ} \mathrm{C}[15,16]$. The chromatographic signal was recorded and further integrated using the software LabSolutions (Shimadzu).

\subsection{Optimization of FFase production}

\subsubsection{Complete factorial design on the production of FFase}

The enzyme production was optimized for the Penicillium strain which FFase activity was higher (Section 2.3: Screening of fungi for FFase production). Two successive full factorial designs $\left(2^{4}\right.$ and $\left.2^{3}\right)$, with three central points, were carriedout to study the effects and interactions of temperature, yeast extract concentration, $\mathrm{pH}$ and fermentation time, on the production of FFase. The variables with statistically influence on the FFase activity were selected for further value optimization (Section 2.6.2: Central composite design on the production of FFase). Experimental conditions used in each assay are shown in Tables 1 and 2, respectively.

\subsubsection{Central composite design on the production of FFase}

A central composite design $\left(2^{2}\right)$ was used to determine the optimal experimental conditions for FFase production. Only the variables found to statistically influence the enzyme production were tested (Section 2.6.1: Complete factorial design on the production of FFase). A 3 levels $(-1,0$ and +1$)$ combination was tested, resulting in a set of 10 experiments, with two central points (Table 3).The regression coefficients for linear, quadratic and interactions for each variable were determined and adjusted to a polynomial second order equation (Eq. (1)).

$Y=\beta 0+\beta_{1} X_{1}+\beta_{2} X_{2}+\beta_{1} X_{1}{ }^{2}+\beta_{1 \beta 2} X_{1} X_{2}+\beta_{2} X_{2}{ }^{2}$

where $Y=$ FFase activity $(U / m L), X_{1}$ the temperature, $X_{2}$ fermentation time and $\beta_{i}$ is the regression coefficient for each factor.

\subsection{Statistical analysis}

The results were analyzed using Statistica 8.0 [17]. Positive effects were considered significant for $p$-values lower than 0.05 [18].

\subsection{Production of FFase in bioreactor}

Fermentations were carried out using the Penicillium strain that obtained higher FFase activity. A $35 \mu \mathrm{L}$ volume of a spore suspension $\left(10^{4}\right.$ spores $/ \mathrm{mL}$ ) was transferred to a $250 \mathrm{~mL}$ shaken flask containing $100 \mathrm{~mL}$ of inoculum medium with the following composition (\% w/v): sucrose, $10.0 ; \mathrm{NaNO}_{3}, 0.2 ; \mathrm{MgSO}_{4} \cdot 7 \mathrm{H}_{2} \mathrm{O}, 0.05$; $\mathrm{K}_{2} \mathrm{HPO}_{4}, 0.5$; and $\mathrm{KCl}, 0.05$.This inoculum was grown for 3 days at $28{ }^{\circ} \mathrm{C}$ and $150 \mathrm{rpm}$ and afterwards transferred to a $2 \mathrm{~L}$ stirred tank bioreactor (Autoclavable Benchtop Fermenter Type R'ALF, 
Table 1

Experimental conditions assayed and respective $\beta$-fructofuranosidase activity values obtained for Penicillium citreonigrum according to a $2^{4}$ complete factorial design.

\begin{tabular}{|c|c|c|c|c|c|}
\hline \multicolumn{5}{|c|}{ Independent variables (real and (coded) values) } & \multirow{2}{*}{$\begin{array}{l}\text { Dependent variable } \\
\text { Activity } \\
\beta \text {-fructofuranosidase } \\
(\mathrm{U} / \mathrm{mL})\end{array}$} \\
\hline Run & Fermentation time $(\mathrm{h})$ & Temperature $\left({ }^{\circ} \mathrm{C}\right)$ & $\mathrm{pH}$ & Yeast extract $(\%(w / v))$ & \\
\hline 1 & $36(-1)$ & $25(-1)$ & $4(-1)$ & $0(-1)$ & 12.03 \\
\hline 2 & $60(+1)$ & $25(-1)$ & $4(-1)$ & $0(-1)$ & 168.85 \\
\hline 3 & $36(-1)$ & $35(+1)$ & $4(-1)$ & $0(-1)$ & 17.08 \\
\hline 4 & $60(+1)$ & $35(+1)$ & $4(-1)$ & $0(-1)$ & 30.66 \\
\hline 5 & $36(-1)$ & $25(-1)$ & $6(+1)$ & $0(-1)$ & 32.89 \\
\hline 6 & $60(+1)$ & $25(-1)$ & $6(+1)$ & $0(-1)$ & 200.99 \\
\hline 7 & $36(-1)$ & $35(+1)$ & $6(+1)$ & $0(-1)$ & 0 \\
\hline 8 & $60(+1)$ & $35(+1)$ & $6(+1)$ & $0(-1)$ & 1.62 \\
\hline 9 & $36(-1)$ & $25(-1)$ & $4(-1)$ & $2.750(+1)$ & 30.10 \\
\hline 10 & $60(+1)$ & $25(-1)$ & $4(-1)$ & $2.750(+1)$ & 195.83 \\
\hline 11 & $36(-1)$ & $35(+1)$ & $4(-1)$ & $2.750(+1)$ & 1.38 \\
\hline 12 & $60(+1)$ & $35(+1)$ & $4(-1)$ & $2.750(+1)$ & 1.90 \\
\hline 13 & $36(-1)$ & $25(-1)$ & $6(+1)$ & $2.750(+1)$ & 60.14 \\
\hline 14 & $60(+1)$ & $25(-1)$ & $6(+1)$ & $2.750(+1)$ & 287.10 \\
\hline 15 & $36(-1)$ & $35(+1)$ & $6(+1)$ & $2.750(+1)$ & 0 \\
\hline 16 & $60(+1)$ & $35(+1)$ & $6(+1)$ & $2.750(+1)$ & 0 \\
\hline 17 & $48(0)$ & $30(0)$ & $5(0)$ & $1.375(0)$ & 261.09 \\
\hline 18 & $48(0)$ & $30(0)$ & $5(0)$ & $1.375(0)$ & 263.56 \\
\hline 19 & $48(0)$ & $30(0)$ & $5(0)$ & $1.375(0)$ & 256.57 \\
\hline
\end{tabular}

Table 2

Experimental conditions assayed and respective $\beta$-fructofuranosidase activity values obtained for Penicillium citreonigrum, according to a $2^{3}$ complete factorial design.

\begin{tabular}{|c|c|c|c|c|}
\hline \multicolumn{4}{|c|}{ Independent variables (real and (coded) values) } & \multirow{2}{*}{$\begin{array}{l}\text { Dependent variable } \\
\text { Activity } \\
\beta \text {-fructofuranosidase }(\mathrm{U} / \mathrm{mL})\end{array}$} \\
\hline Run & Fermentation time $(\mathrm{h})$ & Temperature $\left({ }^{\circ} \mathrm{C}\right)$ & $\mathrm{pH}$ & \\
\hline 1 & $48(-1)$ & $20(-1)$ & $5(-1)$ & 14.73 \\
\hline 2 & $48(-1)$ & $30(+1)$ & $5(-1)$ & 187.12 \\
\hline 3 & $72(+1)$ & $20(-1)$ & $5(-1)$ & 178.09 \\
\hline 4 & $72(+1)$ & $30(+1)$ & $5(-1)$ & 313.33 \\
\hline 5 & $48(-1)$ & $20(-1)$ & $7(+1)$ & 14.10 \\
\hline 6 & $48(-1)$ & $30(+1)$ & $7(+1)$ & 214.75 \\
\hline 7 & $72(+1)$ & $20(-1)$ & $7(+1)$ & 229.37 \\
\hline 8 & $72(+1)$ & $30(+1)$ & $7(+1)$ & 266.68 \\
\hline 9 & $60(0)$ & $25(0)$ & $6(0)$ & 274.52 \\
\hline 10 & $60(0)$ & $25(0)$ & $6(0)$ & 281.83 \\
\hline 11 & $60(0)$ & $25(0)$ & $6(0)$ & 263.61 \\
\hline
\end{tabular}

Bioengineering AG, Wald, Switzerland), using a working volume of $1 \mathrm{~L}$ culture medium with the same composition of the inoculum, except for sucrose, which concentration was adjusted for $20 \%$ $(\mathrm{w} / \mathrm{v})$.Fermentations were performed under temperature and fermentation time conditions previously optimized for the production of FFase, in shaken flask. Samples were collected at 0, 15, 20, 24, 38 , $44,48,60$ and $88 \mathrm{~h}$ of fermentation and filtered through a $0.2 \mu \mathrm{m}$ cellulose acetate membrane for FFase activity and sugars determination. After filtration, the final fermentation broth containing the FFase enzyme produced was also used for FOS enzymatic synthesis.

\subsection{Effect of $\mathrm{pH}$ and temperature on the enzyme stability and} FFase activity

The effect of $\mathrm{pH}$ in the FFase activity was studied in a range between 3.0 and 10.0, by variation of one unity of $\mathrm{pH}$ per assay. Experiments were carried out at $55^{\circ} \mathrm{C}$, for $60 \mathrm{~min}$, using $20 \%(\mathrm{w} / \mathrm{v})$ sucrose in a $0.1 \mathrm{M}$ citrate buffer $(\mathrm{pH} 4.0-6.0)$, sodium phosphate buffer (7.0 and 8.0) and carbonate bicarbonate buffer (9.0 and 10.0). The effect of temperature on the FFase activity was determined for temperatures between 25 and $80^{\circ} \mathrm{C}$, by increasing five degrees per assay. Tests were carried out for $60 \mathrm{~min}$ in $0.1 \mathrm{M}$ citrate buffer ( $\mathrm{pH}$ 6.0). The enzyme $\mathrm{pH}$ stability was estimated by measuring the residual activity after crude extract pre-incubation, at $\mathrm{pH} 3.0-10.0$, for $60 \mathrm{~min}$. Thermal stability of FFase was determined using the value of the residual activity measured after incubation of the crude extract at different temperatures $\left(25-85^{\circ} \mathrm{C}\right)$, for $60 \mathrm{~min}$. The residual activity was measured under standard conditions, as described in Section 2.4.

\subsection{Ions effect on FFase activity}

The effect of the presence of ions at low ( $5 \mathrm{mM})$ and high concentrations $(10 \mathrm{mM})$, on FFase activity was studied. The following salts were tested: $\mathrm{MgSO}_{4}, \mathrm{NaCl}, \mathrm{KCl}, \mathrm{FeCl}_{3}, \mathrm{CuSO}_{4}, \mathrm{FeSO}_{4}, \mathrm{ZnSO}_{4}, \mathrm{ZnCl}_{2}$ and $\mathrm{CaCl}_{2}$. The residual activity was determined after incubation at $37^{\circ} \mathrm{C}$, for $60 \mathrm{~min}$, as described in Section 2.4.

\subsection{Enzymatic synthesis of FOS using FFase extract}

FOS were also synthesized using the extracellular FFase enzymes, produced in bioreactor. The reaction mixture was conducted with $35 \mathrm{~mL}$ of FFase extract and $70 \mathrm{~mL}$ of a sucrose solution (1:3), in shaken flask $(250 \mathrm{~mL})$, at $50^{\circ} \mathrm{C}$ and $150 \mathrm{rpm}$ of agitation for $24 \mathrm{~h}$. The $\mathrm{pH}$ was set to 5.0 before incubation. At the end of incubation, the reaction was stopped by heating the samples for $10 \mathrm{~min}$ at $100^{\circ} \mathrm{C}$. Samples were further diluted, when necessary, and filtered at $0.2 \mu \mathrm{m}$ for FOS and sucrose analysis by HPLC. 
Table 3

Experimental conditions assayed and respective $\beta$-fructofuranosidase activity values obtained for Penicillium citreonigrum according to a $2^{2}$ central composite design.

\begin{tabular}{|c|c|c|c|}
\hline \multicolumn{3}{|c|}{ Independent variables (real and (coded) values) } & \multirow{2}{*}{$\begin{array}{l}\text { Dependent variable } \\
\text { Activity } \\
\beta \text {-fructofuranosidase } \\
(\mathrm{U} / \mathrm{mL})\end{array}$} \\
\hline Run & Fermentation time $(\mathrm{h})$ & Temperature $\left({ }^{\circ} \mathrm{C}\right)$ & \\
\hline 1 & $43(-1)$ & $25(-1)$ & 74.85 \\
\hline 2 & $67(+1)$ & $25(-1)$ & 288.17 \\
\hline 3 & $43(-1)$ & $35(+1)$ & 19.79 \\
\hline 4 & $67(+1)$ & $35(+1)$ & 57.42 \\
\hline 5 & $55(0)$ & $25(-1)$ & 241.95 \\
\hline 6 & $55(0)$ & $35(+1)$ & 42.62 \\
\hline 7 & $43(-1)$ & $30(0)$ & 67.44 \\
\hline 8 & $67(+1)$ & $30(0)$ & 252.70 \\
\hline 9 & $55(0)$ & $30(0)$ & 241.30 \\
\hline 10 & $55(0)$ & $30(0)$ & 239.04 \\
\hline
\end{tabular}
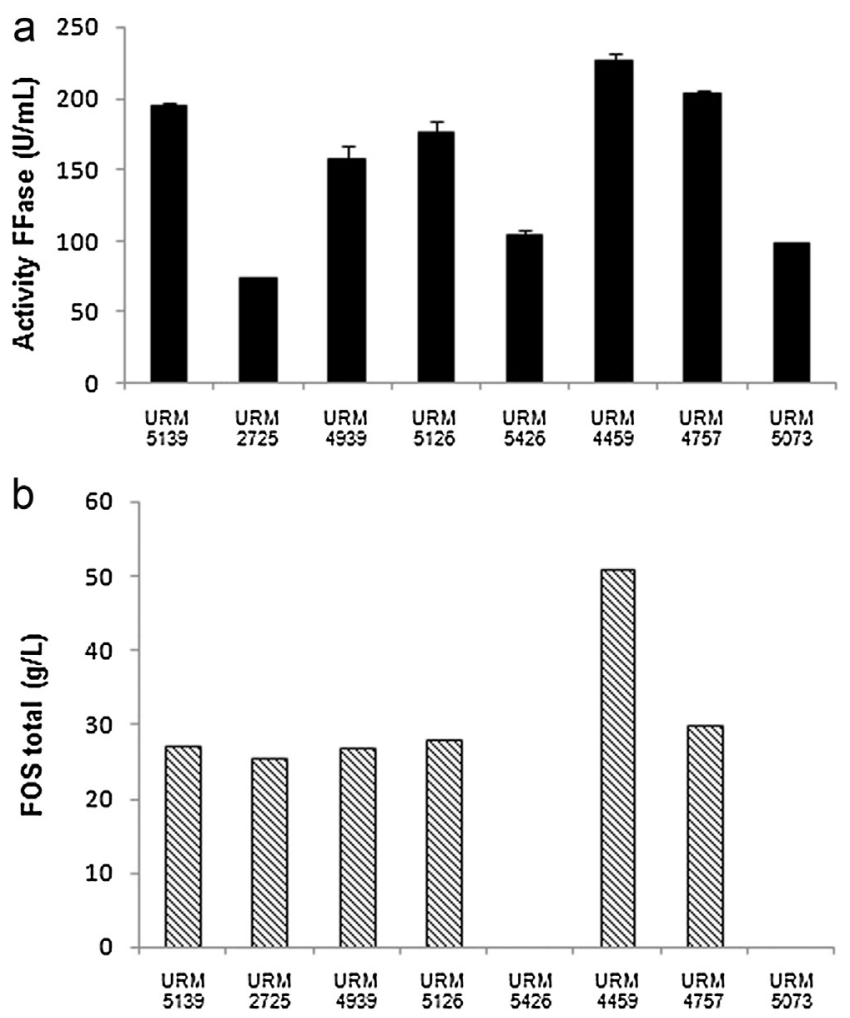

Fig. 1. $\beta$-fructofuranosidase (a) and fructooligosaccharides (b) production by the Penicillium tested, at $36 \mathrm{~h}$ of fermentation. URM $5139-P$. aurantiogriseum, URM $2725-P$. citrinum, URM $4939-P$. citrinum, URM $5126-P$. aurantiogriseum, URM 5426 - P. implicatum, URM 4459 - P. citreonigrum, URM $4757-P$. glabrum, URM $5073-P$. islandicum (abreviattions: FFase $=\beta$-fructofuranosidase, FOS = fructooligosaccharides).

\section{Results and discussion}

\subsection{Screening of fungi for FFase production}

All the eight Penicillium fungi strains tested showed to have transfructosylation activity after $36 \mathrm{~h}$ fermentation (Fig. 1a). The $P$. citreonigrum (UMR 4459) obtained the highest activity of $227.56 \pm 4 \mathrm{U} / \mathrm{mL}$, when compared to the other strains.

Mashitah and Hatijah [19] evaluated the production of FFase enzyme of eleven strains of Penicillium, Aspergillus and Trichoderma. Between the strains studied, Penicillium simplicissimum obtained the higher extracellular FFase production, confirming the potential of the Penicillium genus for FFase production.

To evaluate the sucrose conversion capacity of the FFase enzymes, produced by the eight fungi tested, the amount of sugars contained in the extracellular fermentation mixture were quantified at $36 \mathrm{~h}$ fermentation. Results are shown in Fig. $1 \mathrm{~b}$ as percentage of FOS quantified per total amount of sugars. From Fig. 1 bit is possible to observe that only two strains were not able to convert sucrose into FOS, suggesting that, under the assayed conditions, the extracellular FFase produced by these fungi was limited to sucrose hydrolyze into monosaccharides. Hydrolitic enzymes are usually used for inverted sugar production, at high sucrose concentrations [20]. Other explanation for this phenomenon is the existence of a secondary hydrolysis, wherein the glycosyl hydrolases, belonging to the FFase family, re-hydrolyzes the pre-formed FOS products [21]. In this way, the FOS production becomes limited since an efficient acceptor molecule is necessary for an adequate transglycosilation [22].

P. citreonigrum (URM 4459) produced $50.7 \mathrm{~g} / \mathrm{L}$ of FOS, representing about 26\% more FOS as compared to the following best producer (P. glabrum URM 4757). For this reason, the P. citreonigrum was selected for further optimization tests of FFase and FOS production.

\subsection{Optimization of FFase production}

\subsubsection{Complete factorial design on the production of FFase}

A $2^{4}$ complete factorial design was employed to study the influence of the fermentation time, temperature, $\mathrm{pH}$ and amount of yeast extract used in the FFase activity, of the P. citreonigrum. The highest FFase activity found $(287.10 \mathrm{U} / \mathrm{mL})$ was obtained for the run 14 (Table 1 ), corresponding to $60 \mathrm{~h}$ of fermentation, at $25^{\circ} \mathrm{C}, \mathrm{pH} 6.0$ and $2.75 \%(\mathrm{w} / \mathrm{v})$ of yeast extract.

The Pareto chart, illustrated in Fig. 2, was used for statistical analysis of the variable responses. The figure represents the estimated effects of the independent variables (temperature, fermentation time, $\mathrm{pH}$ and yeast extract concentration) and their interactions on the response. Results are shown in a decreasing order of magnitude, where the length of each bar is proportional to the standardised effect. All the observed results at the right of the vertical red line are statistically significant at $95 \%$ confidence level.

All the variables studied had a statistically significant effect on the FFase activity (Fig. 2). However, the effect of the yeast extract was very low when compared to the other parameters. The increase of yeast extract concentration, above a given value, was already reported in some studies has having a negative effect on the enzyme and FOS production by strains of Aureobasidium pullulans and Aspergillus oryzae [16,23]. Thus, the yeast extract was not added in the culture medium used in the further tests. A second full factorial design $\left(2^{3}\right)$ was employed aiming to further improve FFase activity. The ranges of variables temperature $(20,25$ and $\left.30^{\circ} \mathrm{C}\right)$, fermentation time $(48,60$ and $72 \mathrm{~h})$ and $\mathrm{pH}(5.0,6.0$ and 7.0) were slightly modified, following the trend of the effects of the first design.

Results obtained with the $2^{3} \mathrm{~s}$ full factorial design are shown in Table 2. The effects of each independent variable on the FFase activity can be observed in Fig. 3. From the three variables studied, only two showed a statistically significant effect, the temperature and the fermentation time (Fig. 3). Both variables had a positive effect on the production of FFase, the higher the temperature and the fermentation time, the higher the enzyme production obtained. The highest FFase activity found $(313.33 \mathrm{U} / \mathrm{mL})$ was obtained for the run 4 , corresponding to $72 \mathrm{~h}$ of fermentation, at $30^{\circ} \mathrm{C}$ and $\mathrm{pH} 5.0$ (Table 2).

A negative effect was observed for the interaction between the independent variables temperature and fermentation time indicat- 


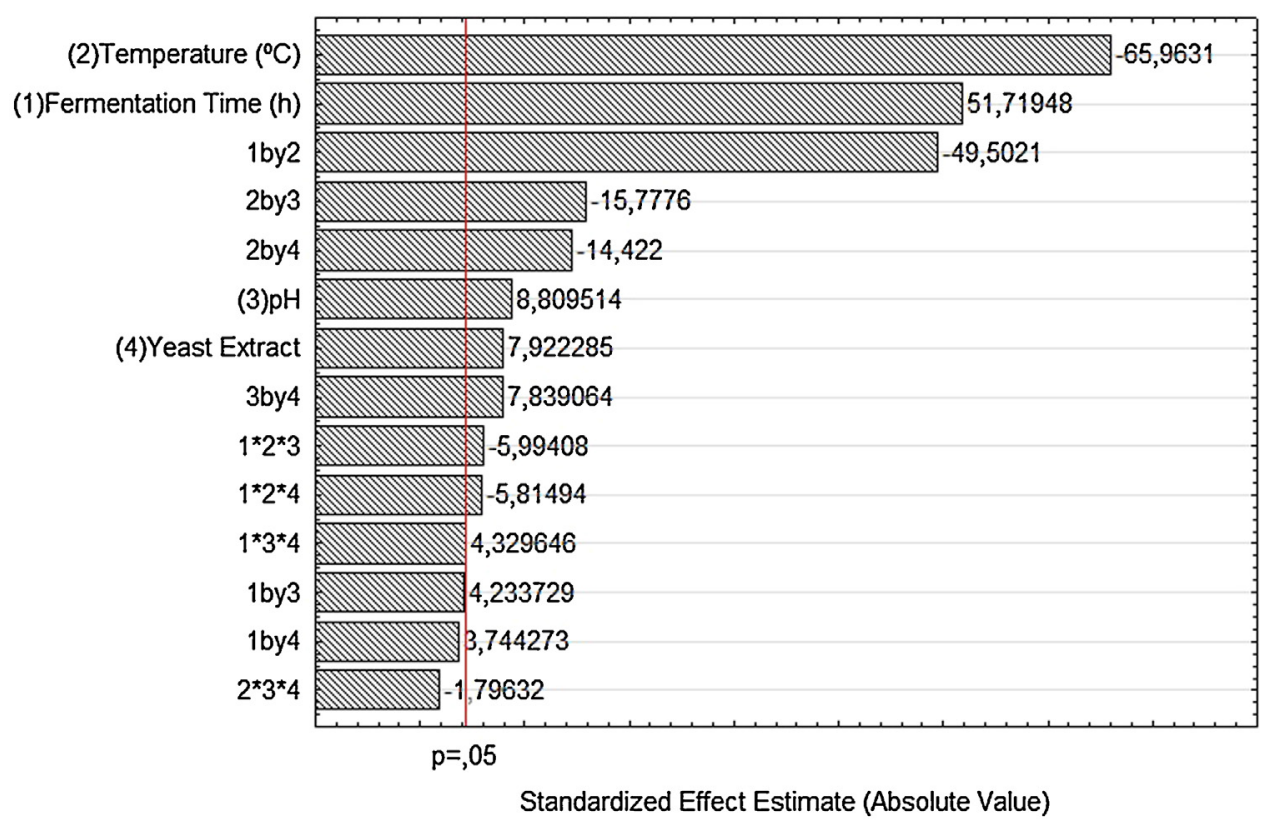

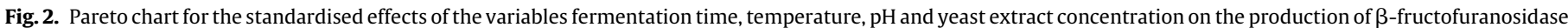
by the Penicillium citreonigrum.

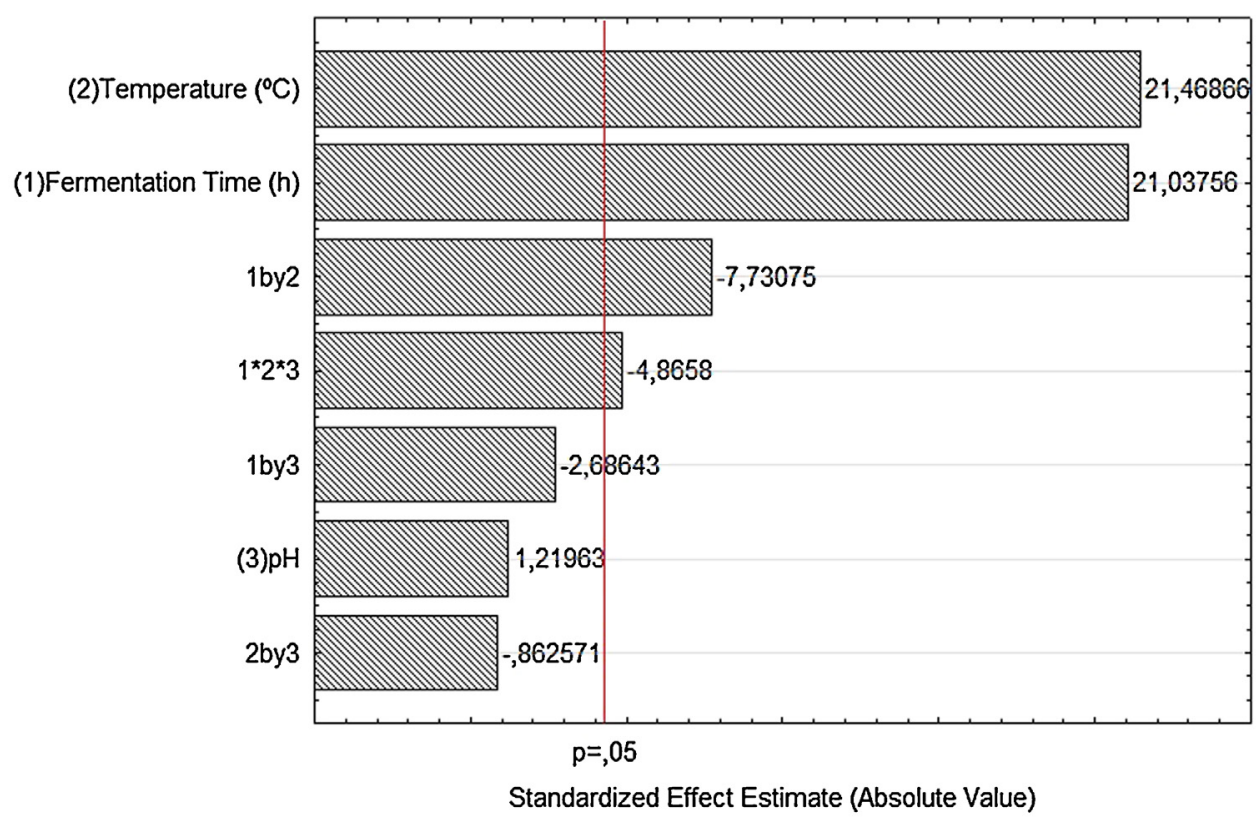

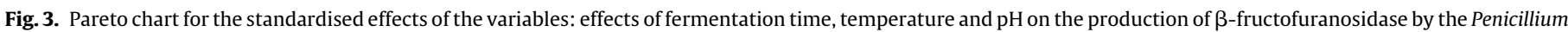
citreonigrum.

ing that, a combination of high temperatures with low fermentation times results in a decreased FFase production (Fig. 3).

Similar results were obtained by Mussatto et al. [24] when studying the effect of temperature on the FFase activity and FOS production by an Aspergillus japonicus. While increasing the temperature from 26 to $30^{\circ} \mathrm{C}$ an increasing of the FFase production was obtained, although, temperatures above $30^{\circ} \mathrm{C}$ showed to have an opposite effect. According to Arumugam et al. [25] high temperatures have generally an adverse effect on the metabolic activity of microorganisms. However, a similar effect might be found for low temperatures. Thus, the temperature used in a fermentation process tends to be a crucial parameter, specially for fungi, since it influences not only the product formation, but also the spore germination and the microorganism growth.

Taking all these considerations into account, the influence of temperature and fermentation time was further optimized using a $2^{2}$ central composite experimental design with three levels (temperature: 25,30 and $35^{\circ} \mathrm{C}$ and fermentation time: 43,55 and $67 \mathrm{~h}$ ). Since the $\mathrm{pH}$ did not show a significant statistically effect on the enzyme production, it was set as constant for all the further fermentations. The further culture mediums used were prepared with an initial $\mathrm{pH}$ of 6.5 . 
Table 4

Analysis of variance (ANOVA) for the second-order model for level optimization of $\beta$-fructofuranosidase production by Penicillium citreonigrum.

\begin{tabular}{|c|c|c|c|c|c|}
\hline Factor & Sum of squares & Degrees of freedom & Mean square & F-value & p-Value \\
\hline (1)Temperature $\left({ }^{\circ} \mathrm{C}\right)(\mathrm{L})$ & 39227 & 1 & 39227 & 15392.76 & 0.005131 \\
\hline Temperature $\left({ }^{\circ} \mathrm{C}\right)(\mathrm{Q})$ & 11607 & 1 & 11607 & 4554.79 & 0.009432 \\
\hline (2)Time $(\mathrm{h})(\mathrm{L})$ & 31714 & 1 & 31714 & 12444.69 & 0.005707 \\
\hline Time (h) (Q) & 6491 & 1 & 6491 & 2547.19 & 0.012612 \\
\hline $1 \mathrm{~L}$ by $2 \mathrm{~L}$ & 7716 & 1 & 7716 & 3027.97 & 0.011568 \\
\hline Lack of Fit & 3562 & 3 & 1187 & 465.91 & 0.034040 \\
\hline Pure Error & 2 & 1 & 2 & & \\
\hline Total SS & 103813 & 9 & & & \\
\hline
\end{tabular}

$\mathrm{R}^{2}=0.966$ and Adj. $\mathrm{R}^{2}=0.923$

a Significant for $p$-values $\leq 0.05$.

\subsubsection{Central composite design on the production of FFase}

The results obtained with the central composite design $\left(2^{2}\right)$ for producing FFase by $P$. citreonigrum are shown in Table 3 . The highest FFase activity found $(288.17 \mathrm{U} / \mathrm{mL})$ was obtained for the run 2 , corresponding to $67 \mathrm{~h}$ of fermentation at $25^{\circ} \mathrm{C}$ temperature (Table 3 ).

An analysis of the variance (ANOVA) of the reduced model was required to confirm both results obtained by graphical methods and the model's adequacy. The results of response surface model of the second order, fitting in the form of ANOVA (Table 4), indicated that the linear and quadratic effects of temperature and fermentation time, and the interaction between variables were significant to the FFase activity response.

The goodness-of-fit of the reduced model was verified by the coefficient of determination $\mathrm{R}^{2}$ that explains $96.6 \%$ of the response variability. Also, the adjusted determination coefficient $\left(\mathrm{R}^{2}\right.$ adjusted $)$ found for the model was 0.923 . This value ensured the satisfactory adjustment of the polynomial model to the experimental data. The $\mathrm{R}^{2}$ adjusted corrects the $\mathrm{R}^{2}$ value for sample size and number of terms in the model. If there are many terms in the model and if the sample size is not very large, the $R^{2}$ adjusted must be noticeably lower than $\mathrm{R}^{2}$ [18]. In our case, the $R^{2}$ adjusted was close to the $\mathrm{R}^{2}$ value, meaning that the $\mathrm{R}^{2}$ value does not need much adjustment.

The model obtained is shown by Eq. (2). The coefficients from the model were obtained by a multiple regression analysis on the experimental data using the least squares method, where $Y$ represents the FFase activity, $\mathrm{X}_{1}$ the temperature and $\mathrm{X}_{2}$ and fermentation time.

$Y=217.9-80.86 X_{1}+72.70 X_{2}-70.53 X_{1}{ }^{2}-43.92 X_{1} X_{2}-52.74 X_{2}{ }^{2}$

All parameters studied, and their interactions were found to have a statistically significant effect on the enzyme production. The effect of the temperature was negative indicating that an increase of the value of this variable above the limits studied would lead to a decrease on the FFase production. On the other hand, the fermentation time had a positive linear effect and a negative quadratic effect, indicating a tendency for maximum production of FFase close to the central point ( $55 \mathrm{~h}$ of fermentation). However, the most important effect was the linear one by increasing the production of FFase with the increasing of the fermentation time, as shown in Fig. 4. The test using minimal temperature $\left(25^{\circ} \mathrm{C}\right)$ and maximal fermentation time $(67 \mathrm{~h})$ obtained an increased FFase production that explains the negative interaction between the temperature and fermentation time.

The three-dimensional response surface described by the model (Eq. (2)), for the studied experimental region, is represented in Fig. 4. Increasing the fermentation time and reducing the temperature, within the range studied, a favorable FFase activity might be found (Fig. 4).

Prata et al. [26] evaluated the effect of the fermentation time on the activity of FFase produced from Penicillium expansum. The authors found that the highest activity $(41 \mathrm{U} / \mathrm{mL})$ was obtained at the end of fermentation ( $48 \mathrm{~h}$ ), using a temperature of $25^{\circ} \mathrm{C}$ under an agitation of $160 \mathrm{rpm}$. In the current work, although the opti-

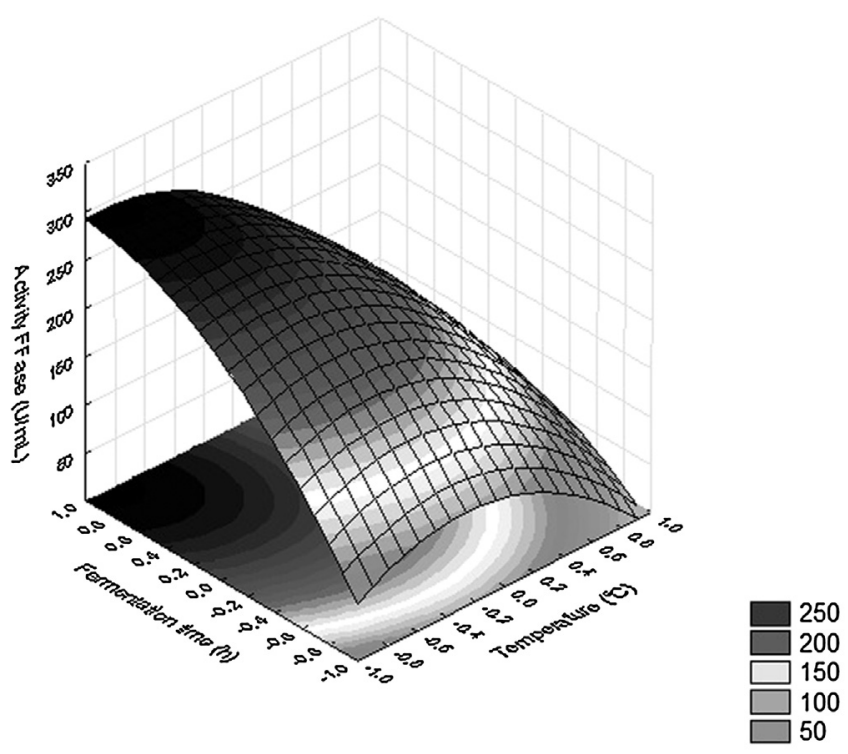

Fig. 4. Response surface obtained in the central composite design for the production of $\beta$-fructofuranosidase (FFase) from Penicillium citreonigrum.

mized fermentation time was higher, the enzymatic activity was seven times higher.

From the central composite design, the optimal conditions found for FFase production by the $P$. citreonigrum, using the proposed model (Eq. (1)), were $25.5^{\circ} \mathrm{C}$ and $67.8 \mathrm{~h}$ for temperature and fermentation time, respectively. Under these conditions, the model predicted a FFase activity of $301.84 \mathrm{U} / \mathrm{mL}$.

\subsection{Production of FFase in bioreactor}

The performance of the FFase production by the $P$. citreonigrum was tested in bioreactor using the optimized conditions found for the shaken flasks experiments. The maximum FFase activity $(232.16 \pm 1 \mathrm{U} / \mathrm{mL}$ ) was found for $38 \mathrm{~h}$ fermentation (Fig. 5). After this time, the enzymatic activity decreased and a reduction of about $40 \%$ of the activity was found for $88 \mathrm{~h}$ fermentation.

Although the FFase activity was lower when the fermentations were scaled-up for the bioreactor, the productivity increased. A maximum productivity of $4.30 \mathrm{U} / \mathrm{mL}$ has achieved in the shaken flask experiments while $6.11 \mathrm{U} / \mathrm{mL}$ h was achieved when using the bioreactor. The productivity increased 1.5 times when scalingup the fermentation. This might be explained due to different microorganism growth conditions when using a shaken flask or a bioreactor. For example, for the bioreactor, the $\mathrm{pH}$ was controlled during the fermentations and, the agitation type on each reactor is considerably different, influencing the mass and air transference, and consequently, the enzyme production. 


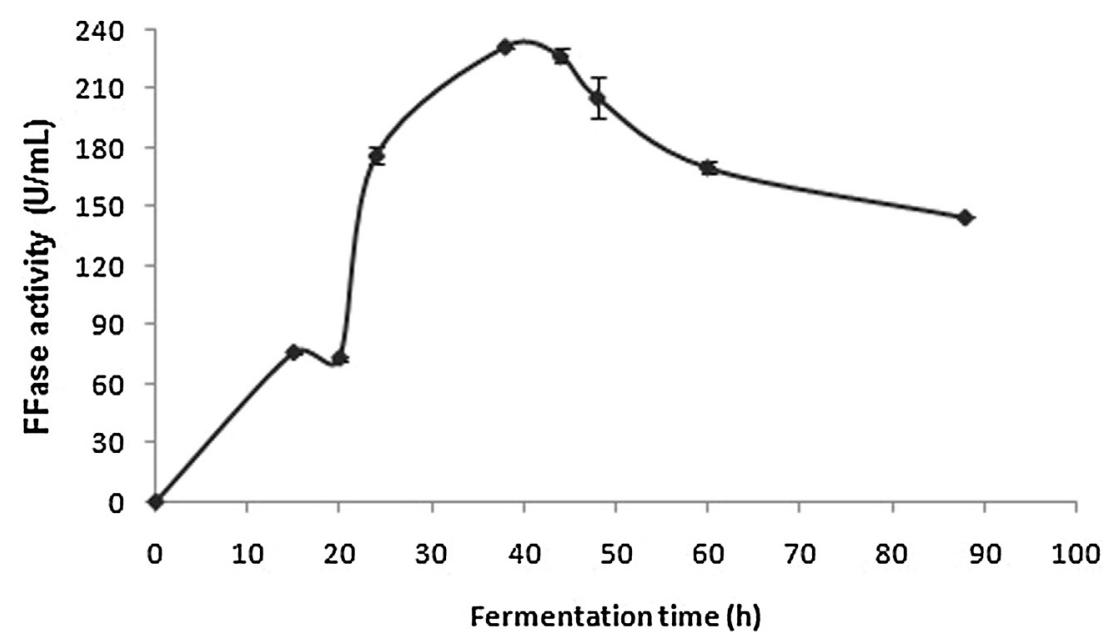

Fig. 5. Production of $\beta$-fructofuranosidase (FFase) from Penicillium citreonigrum in a $2 \mathrm{~L}$ stirred tank bioreactor.

In a work conducted by Driouch et al. [27], using Aspergillus niger for the FFase production in a $3 \mathrm{~L}$ bioreactor (working volume of $2.2 \mathrm{~L}$ ), under operational conditions of temperature and $\mathrm{pH}$ of $37^{\circ} \mathrm{C}$ and 5.0, respectively, the authors obtained the higher FFase production of $80 \mathrm{U} / \mathrm{mL}$ at $100 \mathrm{~h}$ of fermentation $(0.8 \mathrm{U} / \mathrm{mL}$ h productivity). In the present work, the FFase production was about three times higher $(232.16 \mathrm{U} / \mathrm{mL})$ with an eight times higher productivity (6.11 U/mLh).

\subsection{Effect of $\mathrm{pH}$ and temperature on the activity and stability of the FFase}

The pH effect on the FFase activity of a crude extract from $P$. citreonigrum was studied. Results achieved for $\mathrm{pH}$ values ranging between 4.0 and 10.0 are shown in Fig. 6a. The highest FFase activity was found for a $\mathrm{pH}$ of 5.0. However, for a range between 4.0 and 9.0 , the FFase activity did not vary significantly. The FFase was stable over a broad $\mathrm{pH}$ range (4.0-10.0), maintaining its activity always above $90 \%$ (Fig. 6b). This broad range of $\mathrm{pH}$ stability favors its storage and industrial applications [28]. These results are in agreement with previous reports of Xu et al. [28], wherein FFase purified from Penicillium oxalicum was also stable over a pH range of 2.0-9.5.

The optimum temperature found for FFase activity was $50^{\circ} \mathrm{C}$ (Fig. 6c). The crude FFase showed to be stable for $60 \mathrm{~min}$, at a range of $25-30^{\circ} \mathrm{C}$, maintaining its activity above $95 \%$ (Fig. 6d). Similar conditions of temperature and pH were found by Qureshi et al. [29] while using crude extract enzymes from Mucor geophilus.

\subsection{Effects of different ions on FFase activity}

The activity of the crude FFase was increase by $24 \%$ in the presence of $5 \mathrm{mM} \mathrm{Cu}^{4+}$, and $29 \%$ while using a $10 \mathrm{mM}$ concentration of the same ion (Table 5). The enzymatic activity also increased considerably (more than 23\%) in the presence of $\mathrm{Mg}^{4+}, \mathrm{Zn}^{4+}$ and $\mathrm{Zn}^{2+}$ at a concentration of $10 \mathrm{mM}$. Overall, the FFase activity increased when adding ions to the solution, independently on their nature or concentration. Rustiguel, Jorge \& Guimarães [30] reported that metal ions can change the overall charge of proteins, therefore, by affecting their properties, metal ions can interact with the catalytic domains of enzymes reducing or increasing their activities.

\subsection{Enzymatic synthesis of FOS}

The synthesis of FOS, catalyzed by the extracellular FFase from $P$. citreonigrum, was studied. A concentration of $60 \%(\mathrm{w} / \mathrm{v})$ sucrose was
Table 5

Influence of ions on $\beta$-fructofuranosidase activity from Penicillium citreonigrum crude extract.

\begin{tabular}{lll}
\hline \multirow{2}{*}{ Compound } & \multicolumn{2}{l}{ Relative activity (\%) } \\
\cline { 2 - 3 } & $5 \mathrm{mM}$ & $10 \mathrm{mM}$ \\
\hline No addition & 100 & 100 \\
$\mathrm{MgSO}_{4}$ & $119.50^{\mathrm{a}}$ & $123.55^{\mathrm{a}}$ \\
$\mathrm{NaCl}$ & $116.35^{\mathrm{a}}$ & $113.20^{\mathrm{a}}$ \\
$\mathrm{KCl}$ & $113.20^{\mathrm{a}}$ & $114.55^{\mathrm{a}}$ \\
$\mathrm{FeCl}$ & $115.0^{\mathrm{a}}$ & 96.10 \\
$\mathrm{CuSO}_{4}$ & $124.0^{\mathrm{a}}$ & $128.94^{\mathrm{a}}$ \\
$\mathrm{FeSO}_{4}$ & $123.55^{\mathrm{a}}$ & $112.75^{\mathrm{a}}$ \\
$\mathrm{ZnSO}$ & $119.95^{\mathrm{a}}$ & $128.49^{\mathrm{a}}$ \\
$\mathrm{ZnCl}_{2}$ & $117.70^{\mathrm{a}}$ & $127.14^{\mathrm{a}}$ \\
$\mathrm{CaCl}_{2}$ & $118.15^{\mathrm{a}}$ & $116.35^{\mathrm{a}}$ \\
\hline
\end{tabular}

a Statistically significant effects (P-value <0.05).

used as initial carbon source. After $24 \mathrm{~h}$ reaction, only $30 \%$ (w/w) of the initial sucrose was consumed. The final mixture obtained contained $58.7 \mathrm{~g} / \mathrm{L}$ of FOS, mainly composed by $\mathrm{GF}_{2}(52.5 \mathrm{~g} / \mathrm{L})$ with $\mathrm{GF}_{3}$ $(4.5 \mathrm{~g} / \mathrm{L})$ and $\mathrm{GF}_{4}(1.7 \mathrm{~g} / \mathrm{L})$. Fig. 7 shows the chromatogram obtain for this mixture These results imply that FFase from $P$. citreonigrum was not able to use the $\mathrm{GF}_{2}$ synthesized as a fructosyl residue donor to complete the elongation of the glycosidic chain, meaning that almost only sucrose was used as fructosyl donor and acceptor for formation of FOS $[31,32]$. In the present work, $89.5 \%$ of $\mathrm{GF}_{2}$ in total FOS was obtained at the end of fermentation. $\mathrm{GF}_{2}$ is known for its higher sweetner power when compared with the longer chain FOS since the increased fructose chain decreases the sweetening power of FOS [33]. Therefore, it would be interesting using the FFase from $P$. citreonigrum for industrial production of $\mathrm{GF}_{2}$.

\section{Conclusion}

Penicillium citreonigrum was selected as a potential production systems for extracellular FFase. Using RSM it was possible to establish the fermentation conditions $\left(25.5^{\circ} \mathrm{C}, 67.8 \mathrm{~h}\right.$ and $\left.\mathrm{pH} 6.5\right)$ that maximize the FFase production by $P$. citreonigrum in shaken flask, being the maximal FFase activity predicted $301.84 \mathrm{U} / \mathrm{mL}$. The process was scaled-up in a $2 \mathrm{~L}$ stirred tank bioreactor applying the optimized conditions found for the shaken flasks experiments and an 1.5 increase on enzyme productivity $(6.11 \mathrm{U} / \mathrm{mL} . \mathrm{h})$ was achieved. The crude FFase showed stability over a wide range of $\mathrm{pH}$ and temperature and had its activity increased in the presence of several ions. P. citreonigrum synthesized FOS in a content of $58.7 \mathrm{~g} / \mathrm{L}$. The obtained results, although preliminary, are a clear indication on the 

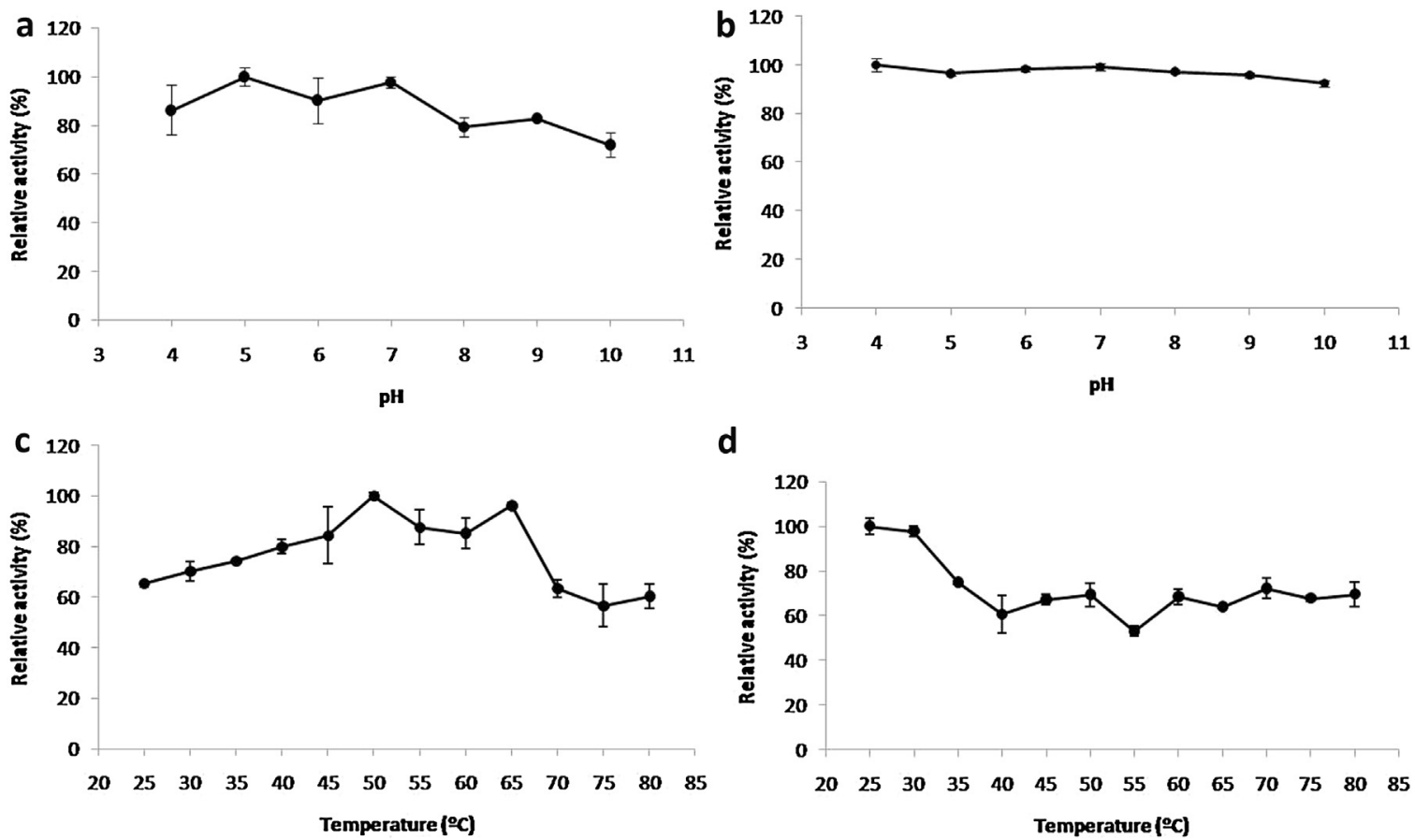

Fig. 6. Optimal pH (a) and temperature (c) and pH (b) and thermal (d) stabilities for the crude $\beta$-fructofuranosidase produced by Penicillium citreonigrum.

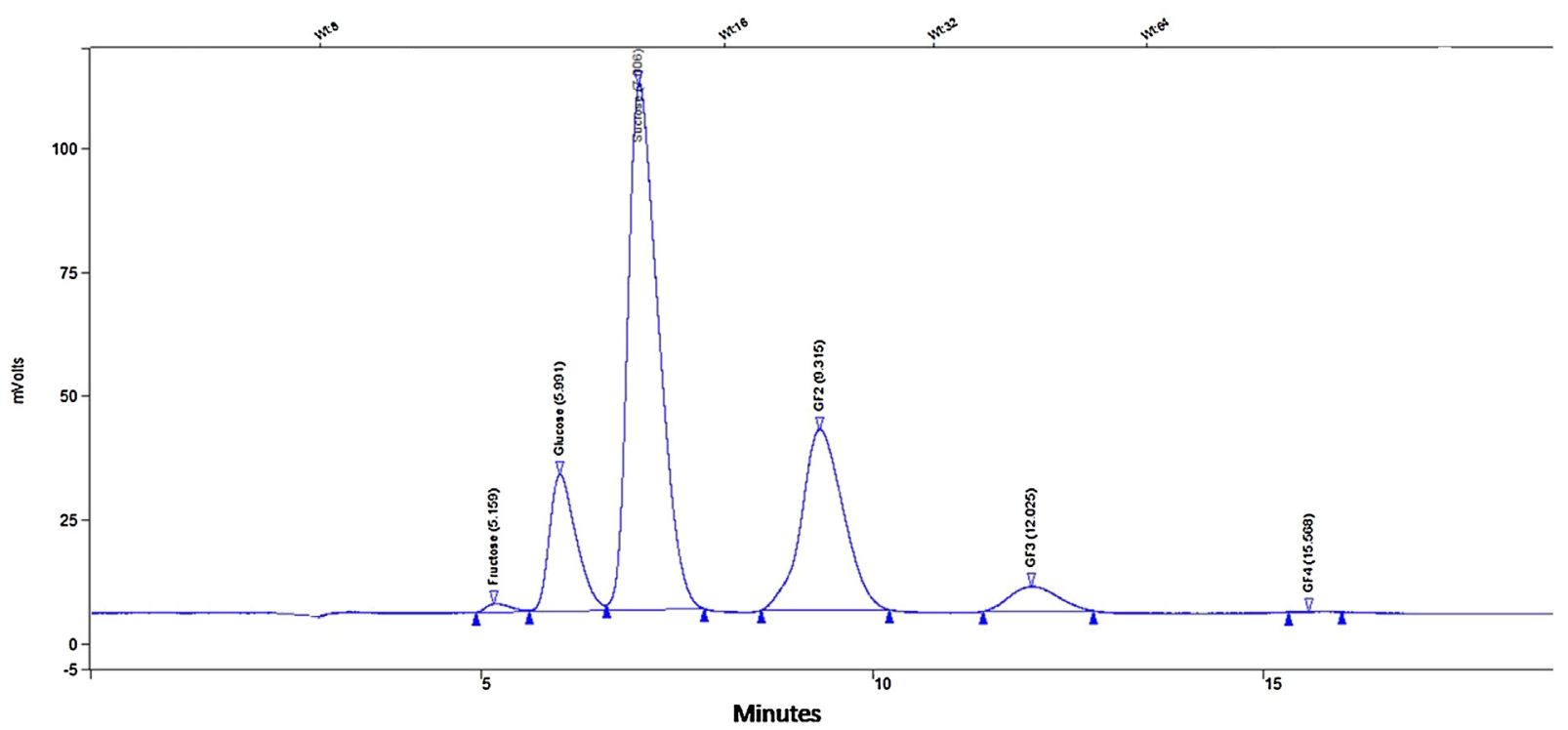

Fig. 7. HPLC chromatogram of the reaction product synthesized by the $\beta$-fructofuranosidase crude extract from Penicillium citreonigrum, with $60 \%$ ( $\mathrm{w} / \mathrm{v}$ ) sucrose at $24 \mathrm{~h}$, $\mathrm{pH}$ 5.0 and $50{ }^{\circ} \mathrm{C}$. (GF 2 :kestose, $\mathrm{GF}_{3}$ :nystose, $\mathrm{GF}_{4}$ : fructofuranosylnystose).

interest of using $P$. citreonigrum as a source of FFase for further use on FOS production.

\section{Acknowledgments}

The authors acknowledge the financial support from the CNPq (Conselho Nacional de Desenvolvimento Científico e Tecnológico, Brasília, Brazil) the approved project in network Renorbio 140366/2014-8, Facepe (Fundação de Amparo à Ciência e Tecnologia do Estado de Pernambuco, Recife, Brasil, AMD-0273-2.00/14) and 0Capes (Coordenação de Aperfeiçoamento de Pessoal de Nível Superior, Brasília, Brazil).Clarisse Nobre acknowledges to Fundação para a Ciência e a Tecnologia (Portugal) and POPH/FSE for the PostDoc Grant received (reference SFRH/BPD/87498/2012).The authors acknowledge the financial support by the Portuguese Foundation for Science and Technology (FCT) under the scope of the strategic funding of UID/BIO/04469/2013 unit and COMPETE 2020 (POCI-01-0145-FEDER-006684) and by the Portuguese Foundation for Science and Technology (FCT) under the scope of the Project RECI/BBB-EBI/0179/2012 (FCOMP-01-0124-FEDER-027462).

\section{References}

[1] W. Vargas, A. Cumino, G.L. Salerno, Cyanobacterial alkaline/neutral invertases. Origin of sucrose hydrolysis in the plant cytosol, Planta 216 (2003) 951-960.

[2] G. Aziani, H.F. Terenzi, J.A. Jorge, L.H.S. Guimarães, Production of fructooligosaccharides by Aspergillus phoenicis biofilm on polyethylene as inert support, Food Technol. Biotechnol. 50 (2012) 40-45. 
[3] A. Dominguez, C. Nobre, L.R. Rodrigues, A.M. Peres, D. Torres, I. Rocha, New improved method for fructooligosaccharides production by Aureobasidium pullulans, Carbohydr. Polym. 89 (2012) 1174-1179.

[4] C. Nobre, J.A. Teixeira, L.R. Rodrigues, New trends and technological challenges in the industrial production and purification of fructo-oligosaccharides, Crit. Rev. Food Sci. Nutr. 55 (2015) 1444-1455.

[5] S. Kralj, K. Buchholz, L. Dijkhuizen, J. Seibel, Fructansucrase enzymes and sucrose analogues: a new approach for the synthesis of unique fructo-oligosaccharides, Biocatal. Biotransform. 26 (2008) 32-41.

[6] P.T. Sangeetha, M.N. Ramesh, S.G. Prapulla, Recent trends in the microbial production, analysis and application of fructooligosaccharides, Trends Food Sci. Technol. 16 (2005) 442-457.

[7] J.W. Yun, Fructooligosaccharides -occurrence, preparation, and application, Enzyme Microb. Technol. 19 (1996) 107-117.

[8] V. De Preter, H.M. Hamer, K. Windey, K. Verbeke, The impact of pre and/or probiotics on human colonic metabolism: does it affect human health? Mol. Nutr. Food. Res. 55 (2011) 46-55.

[9] N.D. Gregory Kelly, Inulin-type prebiotics: a review (Part 2), Altern. Med. Rev. 14 (2009) 36-55.

[10] Prebiotics -A Global Strategic Business Report, Global Industry Analysts, Inc. 2014, http://www.strategyr.com/pressMCP-6079. asp, (accessed: 16.03.16).

[11] M. Elibol, Optimization of medium composition for antinorchodin productionby Streptomyces coelicolor A3 (2) with response surface methodology, Process Biochem. 35 (1999) 1057-1062.

[12] P. Soni, M. Singh, A.L. Kamble, U.C. Banerjee, Response surface optimization of the critical medium components for carbonyl reductase production by Candida viswanathii MTCC 5158, Bioresour. Technol. 98 (2007) 829-833.

[13] S.I. Mussatto, M.B. Prata, L.R. Rodrigues, J.A. Teixeira, Production of fructooligosaccharides and b-fructofuranosidase by batch and repeated batch fermentation with immobilized cells of Penicilliumexpansum, Eur. Food Res. Technol. 235 (2012) 13-22.

[14] M.A. Ganaie, H.K. Rawatb, O.A. Wania, U.S. Guptaa, N. Kango, Immobilization of fructosyltransferase by chitosan and alginate for efficient production of fructooligosaccharides, Process Biochem. 49 (2014) 840-844.

[15] C. Nobre, M.J. Santos, A. Dominguez, D. Torres, O. Rocha, A.M. Peres, I. Rocha, E.C. Ferreira, J.A. Teixeira, L.R. Rodrigues, Comparison of adsorption equilibrium of fructose, glucose and sucrose on potassium gel-type and macroporous sodium ion-exchangeresins, AnalyticaChimicaActa 654 (2009) $71-76$.

[16] C. Nobre, C.C. Castro, A.L. Hantson, J.A. Teixeira, G. De Weireld, L.R. Rodrigues, Strategies for the production of high-content fructo-oligosaccharides through the removal of small saccharides by co-culture or successive fermentation with yeast, Carbohydr. Polym. 136 (2016) 274-281.

[17] Statistica (Data Analysis Software Systems) Version 8.0, StatSoft, Inc, Tulsa OK, USA, 2007.

[18] P.D. Haaland, Experimental Design in Biotechnology, Marcel Dekker Inc., New York, 1989, pp. 76-77.

[19] M.D. Mashitah, S.M. Hatijah, Production of fructosyltransferase by Penicilliumsimplicissimum, Afr. J. Biotechnol. 13 (2014) 4294-4307.
[20] C.B. Rustiguel, A.H.C. Oliveira, H.F. Terenzi, J.A. Jorge, L.H.S. Guimarães, Biochemical properties of an extracellular $\beta$-D-fructofuranosidase II produced by Aspergillus phoenicis under solid-sate fermentation using soy bran as substrate, Electron. J. Biotechnol. 14 (2011) 2.

[21] M. Alvaro-Benito, M. Abreu, L. Fernandez-Arrojo, F.J. Plou, J. Jimenez-Barbero, A. Ballesteros, J. Polaina, M. Fernandez-Lobato, Characterization of a $\beta$-fructofuranosidase from Schwanniomycesoccidentalis with transfructosylatin activity yielding the prebiotic 6-kestose, J. Biotechnol. 132 (2007) 75-81.

[22] F. Maugeri, S. Hernalsteens, Screening of yeast strains for transfructosylating activity, J. Mol. Catal. B: Enzym. 49 (2007) 43-49.

[23] C.A. Ottoni, R. Cuervo-Fernández, R.M. Piccoli, R. Moreira, B. Guilarte-Maresma, E.S. da Silva, M.F.A. Rodrigues, A.E. Maiorano, Media optimization for $\beta$-fructofuranosidase production by Aspergillus oryzae, Braz. J. Chem. Eng. 29 (2012) 49-59.

[24] S.I. Mussatto, L.F. Ballesteros, S. Martins, D.A.F. Maltos, C.N. Aguilar, J.A. Teixeira, Maximization of fructooligosaccharides and $\beta$-Fructofuranosidase production by Aspergillus japonicus under solid-State fermentation conditions, Food Bioprocess Technol. 6 (2013) 2128-2134

[25] G.K. Arumugam, V. Selvaraj, D. Gopal, K. Ramalingam, et al., Solid-State fermentation of agricultural residues for the production of antibiotics, in: S.K. Brar (Ed.), Biotransformation of Waste Biomass into High Value Biochemicals, Springer Science + Business Media, New York, 2014, pp. 139-162.

[26] M.B. Prata, S.I. Mussatto, L.R. Rodrigues, J.A. Teixeira, Fructooligosaccharide production by Penicilliumexpansum, Biotechnol. Lett. 32 (2010) 837-840.

[27] H. Driouch, B. Sommer, C. Wittmann, Morphology engineering of Aspergillus niger for improved enzyme production, Biotechnol. Bioeng. 105 (2010) 1058-1068.

[28] Q. Xu, X. Zheng, M. Huang, M. Wu, Y. Yan, J. Pan, Q. Yang, C. Duan, J. Liu, J. Feng, Purification and biochemical characterization of a novel $\beta$-fructofuranosidase from Penicilliumoxalicum withtransfructosylating activity producing neokestose, Process Biochem. 50 (2015) 1237-1246.

[29] A.S. Qureshi, I. Khushk, M.A. Bhutto, M.U. Dahot, I. Haq, S. Bano, H. Iqbal, Production and partial characterization of invertase from Mucorgeophillus EFRL 03, Afr. J. Biotechnol. 11 (2012) 10736-10743.

[30] C.B. Rustiguel, J.A. Jorge, L.H.S. Guimarães, Characterization of a thermo-tolerant mycelial $\beta$-fructofuranosidase from Aspergillus phoenicis under submerged fermentation using wheat bran as carbon source, Biocatal. Agric. Biotechnol. 4 (2015) 362-369.

[31] M. Antosová, V. Illeová, M. Vandaková, A. Druzkovská, M. Polakovíc, Chromatographic separation and kinetic properties of fructosyltransferase from Aureobasidium pullulans, J. Biotechnol. 135 (2008) 58-63.

[32] M.A. Ganaie, U.S. Guptaa, N. Kango, Screening of biocatalysts fo transformation of sucrose to fructooligosaccharides, J. Mol. Catal. B: Enzym. 97 (2013) 12-17.

[33] J.E. Spiegel, R. Rose, P. Karabell, V.H. Frankos, D.F. Schmitt, Safety and benefits of fructooligosaccharides as food ingredients, Food Technol. 48 (1994) 85-89. 